organisms treated with co-trimoxazole suggests differences in the clinical activities of these drugs. Amoxycillin alone is limited in its activity against urinary pathogens owing to the frequent presence of $\beta$-lactamases. Martinelli et al reported that $36 \%$ of urine isolates were resistant to ampicillin or amoxycillin, ${ }^{3}$ and we found a similar incidence. This resistance can be successfully countered by adding clavulanate to amoxycillin as Augmentin. ${ }^{4}$

The clinical appropriateness of Augmentin is now reinforced by our findings, which show that Augmentin is more rapidly effective than co-trimoxazole in the treatment of urinary tract infection.

We are grateful to Beecham Research Laboratories for supplies of drugs and to Dr K MacRae for statistical advice.

' Matts SGF. The hypnotic and sedative effects of 3 -methyl-3,4-dihydroxy-4-
phenyl-butin-1, a two phase investigation employing double blind techniques and
sequential analysis. Psychopharmacologia (Berlin) $1966 ; 9: 73$.
2 Armitage P. Sequential medical trials. 2nd ed. Oxford: Blackwell Scientific, 1975.
s Martinelli $\mathrm{R}$, Da Silva Lopez AA, De Oliveira MMMG, Rocha H. Amoxycillin-
clavulanic acid in the treatment of urinary tract infections due to Gram-negative
bacteria resistant to penicillin. Antimicrob Agents Chemother $1981 ; 20: 800-2$.
' O'Grady FW. Twenty one years of beating beta-lactamases. Br Med $\mathcal{F} 1982 ; 284$ :
369-70.

(Accepted 2 May 1984)

Groby Road Hospital, Leicester LE3 9QE

G J FANCOURT, MB, MRCP, medical registrar

S G FLAVELL MATTS, MB, FRCP, consultant physician

Public Health Laboratory, Leicester Royal Infirmary, Leicester LE1 5WW

C J MITCHELL, BSC, MRCPATH, director

Correspondence to: Dr S G Flavell Matts.

\section{Evaluation of a gluten free product containing wheat gliadin in patients with coeliac disease}

In coeliac disease a characteristic lesion of the mucosa of the upper small intestine results in malabsorption. Wheat, rye, barley, and possibly oats have been shown to be toxic to patients with coeliac disease. Gliadin, the ethanol soluble fraction of wheat flour, can be divided into $\alpha, \beta, \gamma$, and $\omega$ subfractions, each of which exacerbates coeliac disease. ${ }^{1-3}$ Normal bread contains about $1.25 \mathrm{~g}$ gliadin per standard $30 \mathrm{~g}$ slice. A radioimmunoassay for wheat gliadin showed that bread made from a nominally gluten free flour based on wheat starch contained up to 6.4 mg gliadin per $30 \mathrm{~g}$ slice, ${ }^{4}$ and the product was withdrawn. Juvela and Rite Diet gluten free bread mixes contain only $0.4 \mathrm{mg}$ and $0.2 \mathrm{mg}$ gliadin per $30 \mathrm{~g}$ slice respectively. Although such quantities of gliadin are less than those previously reported to be enterotoxic, ${ }^{3}$ we wanted to test the products in patients with coeliac disease.

\section{Patients, methods, and results}

We studied seven well adult patients with histologically proved coeliac disease who had been receiving a gluten free diet for at least a year. They gave written informed consent and followed a gluten free diet without any commercial gluten free products for one week, when a jejunal biopsy specimen was taken with a Watson jejunal biopsy capsule. They continued the same diet but each day ate six slices of bread that they had baked from Juvela gluten free bread mix. A second jejunal biopsy specimen was taken after the second week.

The biopsy specimens were fixed in formol saline and their dissecting microscopical appearances were assessed blind. Sections were stained with haematoxylin and eosin and assessed blind for the ratio of villus height to crypt depth, the height of epithelial surface cells, and the intraepithelial lymphocyte count. The mean (SD) of 10 observations for each variable was recorded.

The table shows the dissecting microscopical appearances and morphometric measurements of the seven patients before and after challenge. There was no deterioration in the dissecting microscopical appearances of the biopsy specimens except in one patient (case 5) who had broad villi and ridges instead of leaves and villi. The results before and after challenge were: ratio of villus height to crypt depth $2.4(0.7) v 2.0(0.5)$; height of epithelial surface cells $36(5) \mu \mathrm{m} v 33$ (4) $\mu \mathrm{m}$; and intraepithelial lymphocytes 37 (3) $v$ 36 (6) per 100 enterocytes. The fall in the ratio of villus height to crypt depth was significant at the $5 \%$ level, but the other morphometric variables were not significantly different using a paired Student's $t$ test.

\section{Comment}

Gluten free products based on wheat starch have been shown to contain trace amounts of gliadin, ${ }^{45}$ which could be toxic. We have shown previously that $10 \mathrm{mg}$ gliadin by intraduodenal infusion over eight hours did not change the jejunal mucosa in one patient with coeliac disease, although $100 \mathrm{mg}$ gliadin produced minor changes. ${ }^{3}$ Bread made from normal wheat flour contains about $1.25 \mathrm{~g}$ gliadin/ $30 \mathrm{~g}$ slice, while that made from Juvela and Rite Diet gluten free bread mixes contains $0 \cdot 2-0 \cdot 4 \mathrm{mg} /$ slice (unpublished observation).

This study suggests that this nominally gluten free product based on wheat starch is not toxic to patients with coeliac disease when eaten for one week. Further studies are required, however, to exclude possible toxicity of the small amounts of gliadin in these products when eaten daily for long periods. In the meantime they can be recommended to patients with coeliac disease.

PJC and HJE are supported by the Wellcome Trust and thank the Medical Research Council and Drummond Nutrition Trust for previous financial support. We thank Professor R H Dowling and Dr G Sladen for allowing us to study their patients, Dr R P H Thompson for helpful discussion, and Mrs $B$ Issom for typing the manuscript.

' Jos J, Charbonnier L, Mosse J, Olives JP, De Tand MF, Rey J. The toxic fraction of gliadin digests in coeliac disease. Isolation by chromatography on Biogel P-10.

"Howdle PD, Ciclitira PJ, Simpson PG, Losowsky MS. Are all gliadins toxic in coeliac disease ? An in-vitro study of $\alpha, \beta, \gamma$, and $\omega$-gliadins. Scand $\mathcal{f}$ Gastroenterol .

${ }^{3}$ Ciclitira PJ, Evans DJ, Fagg NLK, Lennox ES, Dowling RH. Clinical testing of gliadin fractions in coeliac patients. Clin Sci 1984;66:357-64. "glua PJ, Ellis HJ, Evans DJ, Lennox

Ciclitira PJ, Lennox ES. A radioimmunoassay for $\alpha$ - and $\beta$-gliadins. Clin Sci $1983 ; 64: 655-9$.

(Accepted 9 April 1984)

Gastroenterology Units, United Medical School of Guy's and St

Thomas's Hospitals, London SE1

P J CICLITIRA, MD, MRCP, Wellcome senior research fellow in clinical science

H J ELLIS, BSC, SRD, research assistant and dietitian

Department of Histopathology, Guy's Hospital, London

N L K FAGG, MB, MRCPATH, lecturer in histopathology

Correspondence to: Dr P J Ciclitira, The Rayne Institute, St Thomas's Hospital, London SE1 7EH.

Dissecting microscopical appearance of mucosa, ratio of villus height to crypt depth, height of epithelial surface cells ( $\mu m$ ), and intraepithelial lymphocyte count/100 enterocytes in jejunal mucosal biopsy specimens from seven patients with coeliac disease before and after challenge with gluten free bread (figures are means ( $S D)$ of 10 observations)

\begin{tabular}{|c|c|c|c|c|c|c|c|c|}
\hline \multirow[b]{2}{*}{ Case No } & \multicolumn{2}{|c|}{ Microscopical appearance of mucosa } & \multicolumn{2}{|c|}{ Ratio of villus height to crypt depth } & \multicolumn{2}{|c|}{$\begin{array}{l}\text { Height of epithelial surface cells } \\
\qquad(\mu \mathrm{m})\end{array}$} & \multicolumn{2}{|c|}{$\begin{array}{l}\text { Intraepithelial lymphocyte } \\
\text { count } / 100 \text { enterocytes }\end{array}$} \\
\hline & Before & After & Before & After & Before & After & Before & After \\
\hline $\begin{array}{l}1 \\
2 \\
3 \\
4 \\
5 \\
6 \\
7 \\
\text { Mean }\end{array}$ & $\begin{array}{l}\text { Leaves and ridges } \\
\text { Broad villi and ridges } \\
\text { Leaves and ridges } \\
\text { Broad villi } \\
\text { Leaves and fingers } \\
\text { Ridges } \\
\text { Broad villi and ridges }\end{array}$ & $\begin{array}{l}\text { Leaves and fingers } \\
\text { Broad villi and ridges } \\
\text { Leaves and fingers } \\
\text { Broad villi } \\
\text { Broad villi and ridges } \\
\text { Broad villi } \\
\text { Broad villi and ridges }\end{array}$ & $\begin{array}{l}2.9(0 \cdot 7) \\
1.7(0.6) \\
3.4(0.8) \\
1.4(0.8) \\
2.4(1.0) \\
2.2(0 \cdot 6) \\
2.7(1 \cdot 1) \\
2.4(0.7)\end{array}$ & $\begin{array}{l}1.9(0.4) \\
1.8(0.7) \\
2.9(0.6) \\
1.4(0.6) \\
1.8(0.9) \\
2 \cdot 1(0.8) \\
2.1(0.8) \\
2.0(0.5)\end{array}$ & $\begin{array}{l}35(6) \\
30(1 \cdot 5) \\
38(6) \\
38(10) \\
38(7) \\
43(5) \\
29(2) \\
36(5)\end{array}$ & $\begin{array}{l}34(6) \\
30(5) \\
37(3) \\
26(2) \\
39(5) \\
31(10) \\
34(5) \\
33(4)\end{array}$ & $\begin{array}{l}35(5) \\
36(4) \\
31(4) \\
45(7) \\
33(6) \\
43(6) \\
38(8) \\
37(3)\end{array}$ & $\begin{array}{l}41(5) \\
35(6) \\
32(7) \\
31(5) \\
35(11) \\
48(8) \\
31(9) \\
36(6)\end{array}$ \\
\hline
\end{tabular}

